\title{
Anteseden Senjangan Anggaran Desa di Kabupaten Kebumen
}

\author{
Dian Pertiwi, Arya Samudra Mahardhika \\ Sekolah Tinggi Ilmu Ekonomi Putra Bangsa, Kebumen, Indonesia \\ Email: pdian7535@gmail.com
}

\section{A R T I C L E I N F O}

\author{
Article History: \\ Received: 18 October 2019 \\ Accepted: 31 October 2019 \\ 2019 \\ Keywords: \\ Budgetary Slack \\ Budget Participation \\ Individual Capacity \\ Budget Clarity
}

Available online: 18 November

\begin{abstract}
A B S T R A C T
This study aims to examine the effect of budgetary participation, individual capacity, and clarity of budget targets on village budgetary slack in Kebumen Regency. Respondents in this study are village officials involved in budgeting. The sample in this study was 42 respondents. Data obtained from the distribution of questionnaires directly to respondents. The research hypothesis was tested by multiple regression analysis. The results of this study indicate that; (1) budgetary participation has a positive and significant effect on budgetary slack; (2) individual capacity has no effect on budgetary slack; and (3) clarity of budgetary objectives has a positive and significant effect on budgetary slack.
\end{abstract}

\section{Pendahuluan}

Anggaran merupakan komponen yang sangat penting dalam sebuah organisasi baik sektor publik maupun sektor swasta, karena merupakan sebuah rencana tentang kegiatan dimasa yang akan datang yang mengidentifikasikan kegiatan untuk mencapai tujuan sebuah perusahaan sehingga anggaran harus tercapai secara efektif dan efisien. Penyusunan anggaran berbeda antara sektor swasta dengan sektor pemerintah. Penyusunan anggaran dalam organisasi sektor pemerintah merupakan sebuah proses yang tergolong cukup rumit, karena anggaran sektor publik bukan hanya sebuah rencana tahunan saja, tetapi juga merupakan bentuk akuntabilitas dan transparasi atas pengelolaan publik yang dibebankan kepada pihak daerah.

Undang-Undang Nomor 6 Tahun 2014 Pasal 1 Tentang Desa menyebutkan bahwa desa adalah kesatuan masyarakat hukum yang memiliki batas wilayah yang berwenang untuk mengatur dan mengurus urusan pemerintahan, kepentingan masyarakat setempat berdasarkan prakarsa masyarakat dan hak yang diakui dan dihormati dalam sistem pemerintahan, diantaranya terkait pengelolaan keuangan. Berlakunya Undang-Undang Nomor 6 Tahun 2014 tentang Desa, Kepala Desa harus mengelola keuangan dan aset desa dengan akuntabel dan transparan, profesional, efektif dan efisien, bersih, serta bebas dari korupsi, kolusi dan nepotisme. Permasalahan yang dapat terjadi dalam proses penyusunan anggaran adalah timbulnya senjangan anggaran (budgetary slack) yang merupakan perilaku disfungsional yang dengan sengaja dilakukan dan berpotensi merugikan organisasi atau individu dalam organisasi.

Senjangan anggaran merupakan perbedaan antara jumlah anggaran yang diajukan oleh bawahan dengan jumlah estimasi terbaik yang telah diajukan dan dilakukan pada saat penyusunan anggaran (Anthony \& Govindarajan, 2007). Artinya agent akan membuat target yang lebih mudah 
untuk dicapai dengan cara membuat target anggaran yang lebih rendah pada sisi pendapatan, dan membuat ajuan biaya yang lebih tinggi pada sisi biaya. Hal ini dapat berdampak buruk pada organisasi sektor publik yaitu alokasi sumber daya kurang optimal dan ketidakadilan sumber daya diseluruh unit organisasi. Sehingga dapat menurunkan efisiensi dan merugikan pemangku kepentingan sedangkan ketidakadilan dapat menggagalan manajer unit organisasi yang menerima sumber daya relatif kecil (Miyati, 2014).

Partisipasi anggaran menurut Ikhsan dan Ishak (2005: 173) merupakan suatu proses pengambilan keputusan bersama oleh dua bagian atau lebih pihak dimana keputusan tersebut akan memiliki dampak masa depan terhadap mereka yang membuatnya. Partisipasi anggaran dinilai dapat mengurangi senjangan anggaran apabila bawahan membantu memberikan informasi pribadi tentang prospek masa depan sehingga anggaran yang disusun menjadi lebih akurat, meskipun tidak menutup kemungkinan bahwa semakin besar partisipasi anggaran akan dapat meningkatkan senjangan anggaran (Venusita, 2008).

Sebuah proses penyusunan anggaran sangat terkait dengan beberapa faktor yang muncul di lingkungan kerja dimana sumber daya manusia merupakan modal dasar dalam pelaksanaan pembuatan suatu anggaran. Menurut pendapat Syakhroza (2003), gap yang terjadi dalam implementasi anggaran karena karyawan tidak mempunyai cukup pengetahuan dan pelatihan yang di butuhkan. Oleh karena itu, proses penganggaran membutuhkan kepala desa dan perangkat desa yang mempunyai kapasitas individu yang baik didalamnya. Kapasitas atau kemampuan individu merupakan kesanggupan atau kecakapan yang berarti bahwa seseorang yang memiliki kecakapan atau kesanggupan untuk mengerjakan sesuatu yang diwujudkan melalui tindakannya untuk meningkatkan produktifitas kerja (Nasution, 2011).

Adanya keterlambatan dan kesulitan pemerintah desa dalam penyusunan perencanaan kegiatan dan keuangan desa sebaiknya dijadikan perhatian lebih oleh pemerintah. Diantaranya dengan adanya kejelasasan sasaran anggaran. Kejelasan sasaran anggaran merupakan sejauh mana tujuan anggaran ditetapkan secara jelas dan spesifik dengan tujuan agar anggaran tersebut dapat dimengerti oleh orang yang bertanggungjawab atas pencapaian anggaran tersebut (Erina dan Suartana, 2016). Penyusun anggaran maupun pelaksana anggaran akan lebih mudah dan memiliki informasi yang cukup mengenai sasaran-sasaran anggaran yang dicapai, sehingga dengan adanya sasaran anggaran yang jelas tersebut akan mempermudah penyusun anggaran untuk mempertanggungjawabkan keberhasilan atau kegagalan yang mungkin terjadi.

Berdasarkan temuan penelitian terdahulu yang menunjukan adanya ketidakkonsistenan antara satu peneliti dan penelitian lainya maka penulis termotivasi untuk melakukan penelitian lanjutan dengan variabel-variabel yang diduga memiliki pengaruh terhadap senjangan anggaran, sehingga dapat mendukung riset yang sudah ada dan dapat meminimalisir terjadinya senjangan anggaran. Untuk memberikan gambaran yang lebih jelas mengenai perbedaan hasil temuan tersebut, akan dikemukakan beberapa hasil penelitian yang telah dilakukan oleh peneliti terdahulu. Hasil penelitian Prayudi (2018), Basyir (2016), Erina dan Suartana (2016), Fauziah (2014), Gunadiawan et al (2015) menunjukan partisipasi anggaran berpengaruh positif terhadap senjangan anggaran. Sedangkan penelitian Syahrir (2017); Dunk (1993), Wartono (1998), Minan (2005) dalam Ardinasari (2017) menunjukan bahwa partisipasi anggaran, berpengaruh negatif terhadap senjangan anggaran. Dari permasalahan tersebut perlu dilakukan pembahasan lanjutan.

\section{Tinjauan Pustaka dan Pengembangan Hipotesis}

Beberapa indikasi adanya senjangan pada sektor publik atau pemerintah daerah pada desa di Kabupaten Kebumen dapat dilihat dari senjangan anggaran yang terjadi antara penentuan target dengan realisasi belanja, hal ini terlihat pada tahun 2017, sebanyak 3 desa berhasil melakukan realisasi belanja $100 \%$ dari total 24 desa yang ada. Angka ini menunjukan hanya $12,5 \%$ desa yang berhasil mencapai target belanja. Terdapat beberapa desa dengan 
senjangan anggaran yang cukup tinggi yaitu desa Candiwulan, desa Kembaran dan desa Jemur. Kesimpulan yang dapat diambil adalah hanya sedikit desa yang mampu untuk menetapkan target lebih realitis dan lebih baik. Hal ini sesuai dengan pernyataan Yuhertiana (2004) dalam Miyati (2014) bahwa senjangan anggaran adalah kecendrungan berperilaku tidak produktif dengan melebihkan biaya saat seorang pegawai mengajukan anggaran belanja.

Prayudi (2018), Basyir (2016), Erina dan Suartanana (2016) menyatakan bahwa partisipasi anggaran berpengaruh positif terhadap senjangan anggaran artinya semakin tinggi tingkat partisipasi anggaran, maka senjangan anggaran akan meningkat. Ketika atasan sering kali memberikan wewenang kepada bawahan dengan harapan agar bawahan melakukan usaha yang terbaik untuk organisasi. Akan tetapi bawahan merasa bahwa pencapaian atas anggaran yang mereka susun merupakan penilaian atas kinerja mereka, sehingga penilaian kinerja berdasarkan tercapainya target anggaran daerah dapat menimbulkan situasi dan kondisi yang mmungkinkan seseorang melakukan perilaku yang negatif atau disfungsional.

Hal tersebut didukung oleh agency theory dimana bawahan mempunyai kesempatan yang lebih besar untuk melakukan senjangan agar mempermudah pencapaian target sehingga mengurangi resiko ketidakpastian dalam anggaran. Berdasarkan uraian tersebut hipotesis pertama yang diajukan adalah :

H1: Partisipasi Anggaran berpengaruh positif terhadap senjangan anggaran

Erina dan Suartana (2016) menyatakan bahwa semakin tinggi kapasitas individu,maka senjangan anggaran akan menurun. Kapasitas individu dari beberapa pengambil keputusan terbentuk dari proses pendidikan secara umum, baik melalui pendidikan formal, pelatihan dan pengalaman. Hal ini penting bagi penyusun anggaran dalam menghadapi dan mengantisipasi ketidakpastian lingkungan, terutama isu terkait senjangan anggaran. Organisasi sektor publik perlu menyiapkan tenaga kerja pemerintah yang mempunyai kemampuan yang baik, karena diharapkan dapat meningkatkan kinerja dalam pelayanan publik. Menurut Yuhertiana (2004) individu yang memiliki cukup pengetahuan akan mampu mengalokasikan sumber daya dengan baik, sehingga dapat menurunkan senjangan anggaran. Tetapi Nasution (2011) menyatakan hal yang berbeda bahwa kapasitas individu yang meningkat justru memunculkan senjangan dan sebagai konsekuensi yang muncul dalam penyusunan anggaran. Berdasarkan uraian tersebut hipotesis kedua yang diajukan adalah :

H2: Kapasitas Individu berpengaruh negatif terhadap senjangan anggaran.

Kejelasan sasaran anggaran memberikan kepastian kepada pelaksana anggaran untuk mempertanggung jawabkan keberhasilan maupun kegagalan selama melaksanakan tugasnya untuk mencapaitujuan-tujuan dan sasaran-sasaran yang telah ditetapkan sebelumnya (Suhartono dan Solichin, 2006 dalam Prayudi, 2018). Dengan adanya sasaran anggaranyang jelas, penyusun anggaran maupunpelaksana anggaran akan memilki informasiyang cukup mengenai sasaransasaran anggaran yang akan dicapai dari pada tidak adanya kejelasan sasaran anggaran. Penelitian Prayudi (2018), Erina dan Suartana (2016) menyatakan semakin tinggi kejelasan sasaran anggaran, maka senjangan anggaran akan menurun. Berdasarkan uraian tersebut hipotesis ketiga yang diajukan adalah :

H3: Kejelasan sasaran anggaran berpengaruh negatif terhadap senjangan anggaran

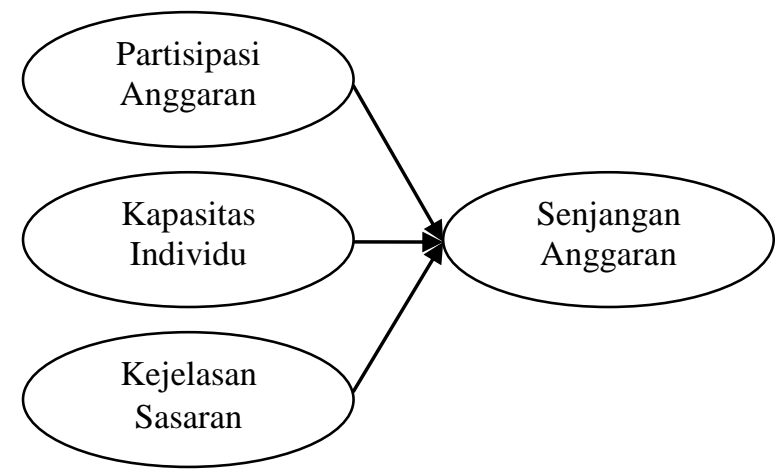

Gambar 1. Model Penelitian

\section{Metode Penelitian}

Penelitian ini dilakukan pada pemerintah desa di Kabupaten Kebumen, yang terdiri atas 24 desa. Sedangkan sampelnya adalah penyusun anggaran pada pemerintah desa di 
Kebupaten Kebumen yang terdiri atas Kepala Desa, Sekretaris Desa, Kaur Keuangan dan Kaur Perencanaan. Teknik pengambilan sampel yang digunakan adalah purposive sampling. Kriteria pemilihan sampel dalam penelitian ini adalah tim penyusun anggaran yang telah bekerja lebih dari satu tahun. Berdasarkan jenis data dan metode analisis data yang digunakan, penelitian ini termasuk dalam jenis penelitian kuantitatif. Data yang digunakan adalah data primer

Instrumen yang digunakan dalam penelitian ini adalah kuesioner yang akan disebar terkait dengan partisipasi anggaran, kapasitas individu dan kejelasan sasaran anggaran terhadap senjangan anggaran. Dalam penelitian ini skala yang digunakan untuk penyusunan kuesioner adalah skala likert 1-5.

Teknik analisis data yang digunakan dalam penelitian ini adalah analisis statistik deskriptif, uji instrumren data yang terdiri dari uji validitas dan uji reliabilitas. Uji asumsi klasik terdiri dari uji normalitas, uji multikolinieritas, dan uji heterokesdatisitas. Uji hipotesis menggunakan uji regresi linier berganda, uji parsial (uji t), uji koefisien determinasi $\left(\mathrm{R}^{2}\right)$. Jumlah kuesioner yang disebar pada penelitian ini sebanyak 70 kuesioner. Dari 70 kuesioner yang disebar hanya 53 kuesioner kembali, dari 53 kuesioner yang kembali hanya 42 kuesioner memenuhi syarat dan dapat diolah. Sehingga kuesioner yang dapat diolah sejumlah 42 kuesioner atau tingkat pengembalian yang dapat dianalisis (useable response rate) sebesar $60 \%$.

Hipotesis dalam penelitian ini diuji menggunakan analisis regresi berganda dengan software SPSS versi 21. Sebelum uji hipotesis dilakukan, data penelitian diujikan terlebih dahulu dengan menggunakan asumsi klasik.

\section{Hasil Penelitian dan Pembahasan}

Uji validitas digunakan untuk mengukur sah atau valid tidaknya suatu kuesioner. Jika korelasi antara masing masing skor butir pernyataan terhadap total skor butir-butir pertanyaan menunjukkan hasil yang signifikan, maka masing-masing butir pernyataan dikatakan valid.

Berdasarkan hasil uji validitas menunjukkan bahwa semua item pertanyaan memiliki nilai Sig. (2-tailed) lebih kecil dari
0,05 dengan nilai Pearson Correlation ( $r$ hitung) lebih besar dari 0,2512 (nilai $r$-tabel untuk $n=42$ ) sebagai syarat valid sehingga seluruh item pertanyaan untuk setiap variabel dinyatakan valid. Partisipasi anggaran, kapasitas individu, kejelasan sasaran anggaran dan senjangan anggaran dinyatakan valid (sah).

Pengujian reliabilitas menunjukan sejauh mana suatu instrumen yang digunakan beberapa ahli untuk mengukur suatu objek yang sama, maka akan mendapatkan data yang sama. Suatu instrumen diatakan reliabel jika nilai Croncbach Alpha > 0,70 (Ghozali, 2009). Berdasarkan hasil pengujian menunjukkan semua variabel memiliki Cronbach's Alpha lebih besar dari 0,70. Jadi dapat disimpulkan bahwa partisipasi anggaran, kapasitas individu, kejelasan sasaran anggaran dan senjangan anggaran adalah reliabel.

Hasil uji normalitas dapat dilihat pada tabel 1. dapat dilihat nilai Asymp. Sig. (2-tailed) sebesar $0,7380>0,05$ maka dapat di simpulkan bahwa data-data penelitian telah berdistribusi normal.

Tabel 1. Hasil Uji Normalitas

\begin{tabular}{|c|c|c|}
\hline & & $\begin{array}{c}\text { Unstandardized } \\
\text { Residual }\end{array}$ \\
\hline $\mathrm{N}$ & & 42 \\
\hline Normal & Mean & 0.0000000 \\
\hline Parameters ${ }^{\mathrm{a}, \mathrm{b}}$ & Std. Deviation & 1.77944317 \\
\hline Most Extreme & Absolute & .105 \\
\hline Differences & Positive & .105 \\
\hline & Negative & -.089 \\
\hline Kolmogornov- & mirnov Z & .684 \\
\hline Asymp. Sig. (2 & tailed) & .738 \\
\hline
\end{tabular}

Uji multikolinieritas bertujuan untuk menguji apakah pada model regresi ditemukan adanya korelasi antar variabel bebas. Dalam penelitian ini berdasarkan Variance Inflation Factor (VIF) dan tolerance. Hasil uji multikolenieritas menunjukkan bahwa nilai tolerance Partisipasi Anggaran 0,520 > 0,1 dan nilai VIF $1,922<10$, nilai tolerance Kapasitas Individu 0,466 > 0,1 dan nilai VIF 2,147 < 10, nilai tolerance Kejelasan Sasaran 0,613 > 0,1 dan VIF 1,631 < 10, Sehingga dapat diketahui bahwa nilai VIF dari masing-masing variabel bebas lebih kecil dari 10 dan nilai tolerance lebih besar dari 0,10. Dengan demikian dapat disimpulkan bahwa di antara variabel bebas tidak ada korelasi atau tidak terjadi multikolinearitas antar variabel bebas. 
Uji heteroskedastisitas bertujuan untuk menguji apakah dalam model regresi terjadi ketidaksamaan varian dari residual satu pengamatan ke pengamatan yang lain. Untuk menguji hiteroskedastisitas digunakan uji Glejser. Berdasarkan hasil pengujian heteroskedastisitas menunjukkan bahwa nilai probabilitas antara data pengamatan dengan residual absolutnya untuk masing-masing variabel diatas taraf signifikan yang ditetapkan yaitu $5 \%$ atau 0,05 . Oleh karena itu penelitian ini telah terbebas dari indikasi heteroskedastisitas.

Koefisien determinasi bertujuan untuk mengukur seberapa jauh kemampuan model dalam menerangkan variasi variabel dependen. Berdasarkan hasil penelitian diperoleh koefisien determinasi sebesar 52,6\%, menunjukkan pengaruh variabel partisipasi anggaran (X1), kapasitas individu (X2), kejelasan sasaran anggaran (X3 mempunyai kontribusi sebesar $52,6 \%$ terhadap senjangan anggaran (Y), sedangkan sisanya $47,4 \%$ dipengaruhi oleh faktor lain yang tidak diteliti. Hasil uji koefesien determinasi disajikan dalam tabel 2:

Tabel 2. Hasil Uji Koefisiensi Determinasi

\begin{tabular}{cccccc}
\hline \multicolumn{6}{c}{ Model Summary $^{\mathbf{b}}$} \\
$\begin{array}{c}\text { Mod } \\
\text { el }\end{array}$ & $\mathrm{R}$ & $\begin{array}{c}\mathrm{R} \\
\text { Square }\end{array}$ & $\begin{array}{c}\text { Adjusted } \\
\text { R Square }\end{array}$ & $\begin{array}{c}\text { Std. Error } \\
\text { of the } \\
\text { Estimate }\end{array}$ & $\begin{array}{c}\text { Durbin- } \\
\text { Watson }\end{array}$ \\
\hline 1 & $.749^{\mathrm{a}}$ & .560 & .526 & 184.835 & 2.222 \\
\hline
\end{tabular}

Analisis regresi linier berganda digunakan untuk memprediksi pengaruh lebih dari satu variabel bebas terhadap satu variabel terikat. Model regresi dalam penelitian ini adalah untuk menguji variabel partisipasi anggaran (X1), Kapasitas individu (X2), kejelasan sasaran anggaran (X3 terhadap senjangan anggaran (Y). Hasil analisis regresi linier berganda dapat dilihat dalam tabel 3:

Tabel 3. Hasil Uji Regresi Berganda

\begin{tabular}{|c|c|c|c|c|c|}
\hline \multicolumn{6}{|c|}{ Coefficients $^{\mathrm{a}}$} \\
\hline \multirow{3}{*}{ Model } & \multicolumn{3}{|c|}{ Unstandardized Standardized } & \multirow{3}{*}{$\mathrm{t}$} & \multirow{3}{*}{ Sig. } \\
\hline & \multicolumn{2}{|c|}{ Coefficients } & \multirow{2}{*}{$\begin{array}{c}\text { Coefficients } \\
\text { Beta }\end{array}$} & & \\
\hline & B & $\begin{array}{l}\text { Std. } \\
\text { Error }\end{array}$ & & & \\
\hline Constant & 3.580 & 2.767 & & 1.294 & .204 \\
\hline $1 \mathrm{X} 1$ & .443 & .142 & .465 & 3.116 & .003 \\
\hline $\mathrm{X} 2$ & -.212 & .137 & -.244 & -1.548 & .130 \\
\hline $\mathrm{X} 3$ & .551 & .133 & .568 & 4.138 & .000 \\
\hline
\end{tabular}

Hipotesis pertama yang diajukan dalam penelitian ini adalah partisipasi anggaran berpengaruh positif terhadap senjangan anggaran. Berdasarkan hasil yang disajikan tabel menunjukkan bahwa koefesien variabel partisipasi anggaran sebesar 0.443 dengan hasil uji t-test diperoleh hasil t-hitung 3.116 lebih besar dari t-table yaitu sebesar $3.116>$ 1.685 dengan nilai signifikansi sebesar $0.003<$ 0,05 , sehingga dapat disimpulkan hipotesis pertama diterima yakni partisipasi anggaran berpengaruh positif dan signifikan terhadap senjangan anggaran desa di Kabupaten Kebumen. Artinya ketika partisipasi anggaran yang dilakukan oleh bawahan semakin besar, maka akan menimbulkan senjangan anggaran yang semakin besar pula. Senjangan anggaran timbul karena bawahan yang ikut berpartisipasi dalam penyusunan anggaran memberikan informasi yang bias kepada principal (rakyat), padahal bawahan (agent) memiliki informasi yang dapat digunakan untuk membantu keakuratan anggaran organisasi. Sehingga principal (rakyat) harus ikut langsung berpartisipasi aktif atau memantau proses penyusunan anggaran. Tanpa adanya partisipasi dari principal (rakyat), akan menimbulkan kecenderungan para bawahan untuk mengusulkan anggaran yang mudah dicapai, atau menyampaikan anggaran yang memungkinkan adanya hal-hal yang tidak terduga sehingga dapat terhindar dari kegagalan. Hasil penelitian ini sejalan dengan hasil Erina dan Suartana (2016), Prayudi (2018), Basyir (2016), Fauziah (2014), Yuhertiana (2004) yang menyimpulkan partisipasi anggaran berpengaruh positif dan signifikan terhadap senjangan anggaran. Artinya semakin tinggi partisipasi anggaran maka senjangan nya meningkat.

Hipotesis kedua yang diajukan dalam penelitian ini adalah Kapasitas Individu berpengaruh negatif terhadap senjangan anggaran. Berdasarkan hasil yang disajikan tabel menunjukkan bahwa koefesien variabel kapasitas individu sebesar -0.212 dengan hasil uji $t$-test diperoleh hasil t-hitung -1.548 lebih kecil dari $t$-table yaitu sebesar $-1.548<1.685$ dengan nilai signifikansi sebesar $0.130>$ dari 0,05 , sehingga dapat disimpulkan bahwa hipotesis kedua ditolak artinya kapasitas individu tidak berpengaruh terhadap senjangan anggaran dan didapat arah hubungan variabel kapasitas individu terhadap senjangan 
anggaran adalah negatif tetapi tidak signifikan. Berdasarkan arah hubungan negatif tersebut, dapat dinyatakan bahwa kapasitas individu berpengaruh negatif namun tidak signifikan. Artinya semakin tinggi kapasitas individu maka senjangan anggaran menurun. Namun indikasi untuk kapasitas individu masih sangat kecil karena hasil analisis yang didapat tidak signifikan. Hal ini disebabkan karena kapasitas individu merupakan perpaduan dari kemampuan dan ketrampilan seorang penyusun anggaran sehingga tidak dapat digunakan untuk menilai tingkat motivasinya dalam melakuan kesenjangan anggaran (Ardinasari, 2017). Hasil penelitian ini tidak sesuai dengan penelitian Basyir (2016), Erina dan Suartana (2016), Gunadiawan et al (2015) yang menyimpulkan kapasitas individu berpengaruh negatif dan signifikan terhadap senjangan anggaran.

Hipotesis ketiga yang diajukan dalam penelitian ini adalah Kejelasan Sasaran Anggaran berpengaruh negatif terhadap senjangan anggaran. Berdasarkan hasil yang disajikan tabel menunjukkan bahwa koefesien variabel kejelasan sasaran anggaran sebesar 0.551 dengan hasil uji $t$-test diperoleh hasil thitung lebih besar dari t-table yaitu sebesar $4.138>1.685$ dengan nilai signifikansi sebesar $0,00<$ dari 0,05 , sehingga dapat disimpulkan bahwa hipotesis ketiga diterima artinya kejelasan sasaran anggaran berpengaruh signifikan terhadap senjangan anggaran dan didapat arah hubungan positif. Hasil penelitian ini menunjukan bahwa semakin tinggi tingkat kejelasan sasaran anggaran maka akan berdampak pada peningkatan senjangan anggaran. Hal ini dikarenakan sasaran anggaran dan anggaran seringkali ditentukan pada periode sebelumnya sehingga anggaran akan bersifat kaku dan susah untuk disesuikan dengan keadaan yang sesungguhnya (Gunadiawan et al 2015). Selain itu penerapan anggaran dengan sasaran yang jelas dapat memudahkan penyusun anggaran mengetahui secara pasti sasaran yang akan dicapai karena penyusun anggaran memiliki infomasi lebih mengenai kejelasan sasaran anggarandibandingkan dengan atasannya, sehingga memperbesar kemungkinan bawahan akan bermain dalam anggaran diantaranya melakukan senjangan anggaran.
Hasil penelitian ini bertentangan dengan penelitian yang dilakukan oleh Prayudi (2018) dan Erina dan Suartana (2016) yang menyatakan bahwa kejelasan sasaran anggaran berpengaruh negatif terhadap senjangan anggaran. Namun penelitian ini sejalan dengan penelitian yang dilakukan oleh Gunadiawan et al. (2015), Fauziah (2014) dan Biantara dan Putri (2014). Yang menyimpulkan kejelasan sasaran anggaran berpengaruh positif dan signifikan terhadap senjangan anggaran.

\section{Kesimpulan}

Berdasarkan hasil analisis data dan pembahasan yang telah diuraikan, maka dapat ditarik kesimpulan sebagai berikut; (1) Partisipasi anggaran berpengaruh positif dan signifikan terhadap senjangan anggaran desa di Kabupaten Kebumen; (2) Kapasitas individu berpengaruh negatif dan tidak signifikan terhadapsenjangan anggaran desa di Kabupaten Kebumen; (3) Kejelasan sasaran anggaran berpengaruh positif dan signifikan terhadap senjangan anggaran desa di Kabupaten Kebumen.

Berdasarkan hasil penelitian serta kesimpulan yang diperoleh dari penelitian ini, adapun saran yang ingin disampaikan antara lain; (1) Bagi pemerintah desa perlu dilakukan pengendalian internal yang lebih memadai dalam pelaksanaan anggaran di desa di Kabupaten Kebumen dengan cara lebih selektif dalam menentukan individu yang ikut berpartisipasi dalam penganggaran seperti memilih dan melibatkan penyusun anggaran yang mengerti dan bertanggung jawab atas dibuatnya anggaran; (2) Mengingat bahwa kejelasan sasaran anggaran berpengaruh positif terhadap senjangan anggaran, maka saran yang diberikan peneliti untuk pemerintah desa di Kabupaten Kebumen yaitu atasan hendaknya memeriksa kembali anggaran yang diusulkan aparat secara seksama sehingga timbulnya senjangan dapat diminimalisir; (3) Penelitian selanjutnya disarankan untuk melakukan penelitian lanjutan dengan menambah variabel-variabel lainnya yang berhubungan dengan hal-hal yang memungkinkan berpengaruh terhadap senjangan anggaran seperti penekanan anggaran, asimetry informasi, self esteem dan lain sebagainya. 


\section{Daftar Pustaka}

Anthony, R.N., \& Govindarajan, V. (2007). Management Control System. MC Graw-Hill Co. Boston.

Ardinasari, I. F. (2017). Kapasitas Individu, Budaya Organisasi, Dan Asimetri Informasi Pada Penyusunan Anggaran Partisipatif Terhadap Budgetary Slack (Studi Kasus SKPD Sleman). Skripsi Tidak dipublikasikan. Fakultas Ekonomi. Universitas Negeri Yogyakarta.

Basyir, A. A. (2016). Pengaruh Partisipasi Anggaran, Informasi Asimetri, dan Kapasitas Individu Terhadap Bugdetary Slack Pada SKPD Pemerintah Kota Samarinda. Jurnal Ekonomi Keuangan, 13(2).

Biantara, A.A.A., \& Putri, IG.A.M.A.D. (2014). Pengaruh Kejelasan Sasaran Anggaran, Etika, Dan Kepercayaan Diri Pada Senjangan Anggaran. E-Jurnal Akuntansi Universitas Udayana, Vol 9 No. 2. pp. 385-391.

Erina, N. P. D. \& Suartana, W. (2016). Pengaruh Partisipasi Anggaran, Penekanan Anggaran, Kapasitas Individu, Dan Kejelasan Sasaran Anggaran Pada Senjangan Anggaran. E-Jurnal Akuntansi Universitas Udayana, 15(2), 9731000.

Fauziah. (2014). Pengaruh Partisipasi Anggaran Dan Kejelasan Sasaran Anggaran Terhadap Senjangan Anggaran Pada Pemerintah Kota Tanjung Pinang. Skripsi Tidak dipublikasikan. Universitas Maritim Raja Ali Haji. Tanjung Pinang.

Ghozali, I. (2009). Aplikasi Analisis Multivariate Dengan Program SPSS, Edisi Keempat. Penerbit Universitas Diponegoro. Semarang.

Gunadiawan, I.W.F., Sinarwati, N.K., \& Sujana, E. (2015). Pengaruh Partisipasi Anggaran, Penekanan Anggaran, Kapasitas Individu dan Kejelasan Sasaran Anggaran terhadap Senjangan Anggaran (Studi Empiris Pada
SKPD Kabupaten Bangli). Jurnal Ilmiah Mahasiswa Akuntansi Undiksha, Vol. 3 No. 1.

Ikhsan, A \& Ishak, M. (2005). Akuntansi Keprilakuan. Salemba Empat. Jakarta

Nasution, E.Y. (2011). Analisis Kapasitas Individu, Partisipasi Penganggaran dan Kesenjangan Anggaran pada Satuan Kerja Perangkat Daerah Kabupaten Langkat. Tesis tidak dipublikasikan. Universitas Sumatera Utara. Medan.

Miyati. (2014). Pengaruh Partisipasi Anggaran Terhadap Budgetary Slack Dengan Pertimbangan Etika Sebagai Variabel Moderasi. Skripsi tidak dipublikasikan. Fakultas Ekonomi. Universitas Negeri Yogyakarta

Prayudi, Y. D. (2018). Pengaruh Partisipasi Anggaran, Penekanan Anggaran, Kejelasan Sasaran Anggaran dan Self Esteem Terhadap Senjangan Anggaran Desa di Kecamatan Kubutambahan. E-Journal S1 Ak Universitas Pendidikan Ganesha, 8(2).

Republik Indonesia. Undang-Undang Nomor 6 Tahun 2014 Tentang Desa.

Syakhroza, A. (2003). Political Games in Budgeting Process of Gooverment Manufacturing Enterprises in Indonesia: A Qualitative Approach. Usahawan. No.5 Tahun XXXII.

Venusita, L. (2008). Partisipasi Anggaran dan Keterlibatan Kerja terhadap Senjangan Anggaran dengan Komitmen Organisasi sebagai Variabel Moderasi (Studi pada Perusahaan Industri Food and Beverage di Kawasan Industri SIER). Jurnal Kewirausahaan, Vol. 2 No. 1. pp. 27-42.

Yuhertiana, I. (2004). Kapasitas Individu dalam Dimensi Budaya, Keberadaan Tekanan Sosial dan Keterkaitannya dengan Budgetary slack. Kumpulan Materi Simposium Nasional Akuntansi VII, Denpasar Bali. 